\title{
Evaluation of the cytotoxic and genotoxic potential of water from the River Paraíba do Sul, in Brazil, with the Allium cepa L. test
}

\author{
Barbério A. ${ }^{\mathrm{a}, \mathrm{b}^{*}}$, Barros L. ${ }^{\mathrm{a}}$, Voltolini JC. ${ }^{\mathrm{b}}$ and Mello MLS. ${ }^{\mathrm{a}}$ \\ ${ }^{a}$ Departamento de Biologia Celular, Instituto de Biologia, Universidade Estadual de Campinas - UNICAMP, \\ Rua Monteiro Lobato, 255, Cidade Universitária Zeferino Vaz, CEP 13083-862, Campinas, SP, Brazil \\ 'Departamento de Biologia, Universidade de Taubaté - UNITAU, \\ Av. Tiradentes, 500, Bom Conselho, CEP 12030-180, Taubaté, SP, Brazil \\ *e-mail: agnesbarberio@yahoo.com.br \\ Received April 10, 2008 - Accepted June 17, 2008 - Distributed August 31, 2009
}

(With 3 figures)

\begin{abstract}
This work investigated the cytotoxic and genotoxic potential of water from the River Paraíba do Sul (Brazil) using Allium cepa roots. An anatomo-morphological parameter (root length), mitotic indices, and frequency of micronuclei were analysed. Eight bulbs were chosen at random for treatment for 24 to 120 hours with the River water collected in the years of 2005 and 2006 from sites in the cities of Tremembé and Aparecida (São Paulo state, Brazil). Daily measurements of the length of the roots grown from each bulb were carried out throughout the experiment. Mitotic index (MI) and frequency of micronuclei (MN) were determined for 2000 cells per root, using 3-5 root tips from other bulbs (7-10). Only in the roots treated with samples of the River water collected in 2005 in Tremembe city was there a decrease in the root length growth compared to the respective control. However, a reduction in MI values was verified for both sites analysed for that year. Considering the data involving root length growth and especially MI values, a cytotoxic potential is suggested for the water of the River Paraíba do Sul at Tremembé and Aparecida, in the year of 2005. On the other hand, since in this year the MN frequency was not affected with the river water treatments, genotoxicity is not assumed for the river water sampled at the aforementioned places.
\end{abstract}

Keywords: cytotoxicity, genotoxicity, Allium cepa, mitotic index, River Paraíba do Sul.

\section{Avaliação do potencial citotóxico e genotóxico da água do Rio Paraíba do Sul através do teste Allium cepa}

\section{Resumo}

Este trabalho é parte de uma investigação sobre o potencial citotóxico e genotóxico da água do Rio Paraíba do Sul (Brasil) utilizando raízes de Allium cepa. Foi analisado um parâmetro anátomo-morfológico (crescimento das raízes), bem como o índice mitótico e a frequência de micronúcleos. Aleatoriamente oito bulbos foram submetidos aos tratamentos de 24 a 120 horas com água do Rio proveniente dos pontos de coleta das cidades de Tremembé e Aparecida nos anos de 2005 e 2006. O comprimento das raízes de cada bulbo foi acompanhado diariamente ao longo do experimento. O índice mitótico (IM) e a frequência de micronúcleos $(\mathrm{MN})$ foram determinados pela análise de 2.000 células por raiz, sendo utilizadas 3-5 raízes de outros bulbos (7-10). Somente as raízes tratadas com amostras de água coletadas em 2005 na cidade de Tremembé, apresentaram decréscimo no comprimento das raízes quando comparadas com o controle. Entretanto, foi observada redução do IM nas raízes tratadas com água de ambos os pontos de coleta no mesmo ano. Considerando os dados de crescimento de raiz e especialmente IM, um potencial citotóxico é sugerido para a água do Rio Paraíba do Sul em Tremembé e Aparecida, no ano de 2005. Por outro lado, para este mesmo ano, a frequência de micronúcleos não foi alterada; assim, a genotoxicidade não foi assumida para a água do Rio nos pontos mencionados.

Palavras-chave: citotoxicidade, genotoxicidade, Allium cepa, índice mitótico, Rio Paraíba do Sul.

\section{Introduction}

The human population in developing countries has been suffering the effects of the pollution generated by increasing urbanization and industrialization. A preventive measure to detect the environmental hazards that infringe the human health should be established on a global scale.
In a broad sense, since humans are ultimately a part of the ecosystem, ecosystem health encompasses human health.

In Brazil, river water quality has been regulated since March $17^{\text {th }}, 2005$ by CONAMA (National Council of the Environment) resolution number 375 , which classifies wa- 
ters and determines their physical and chemical parameters, seeking to control the disposal of pollutants in the environment under levels not harmful to man, other animals and plants. There is a concern related with the precision of established tolerated levels, because some studies have shown that, for certain parameters, even low values may be associated with genotoxic effects (Matsumoto et al., 2006).

Like many other rivers receiving supposedly toxic elements from their effluents, contributed by residues from industries, agriculture and domestic sewage, the River Paraíba do Sul, located in southeastern Brazil, requires monitoring for possible toxic effects of its water. This River provides energy generation, urban water supply, assimilation of urban, industrial and agricultural wastes, and irrigation, among many benefits, for an extensive area. Consequently, there is a growing concern regarding environmental pollution in this River.

Pollutants with mutagenic and cytotoxic potentials produce effects such as DNA fragmentation, induction of chromosome aberrations, inhibition of cellular division, and arrest of the cellular cycle, that can be cytologically detected (Grant, 1999; Evseeva et al., 2003).

Among the bioassays developed for detection of mutagenicity, genotoxicity, cytotoxicity and clastogenicity due to environmental pollutants, plant systems have proven to be sensitive, cheap, and effective (Gopalan, 1999; Cabrera and Rodriguez, 1999a,b; Cabrera et al., 1999; Grant, 1999; Ma, 1999; Majer et al., 2005). Plant bioassays, which are mostly sensitive for the detection of genotoxicity, may provide a warning of environmental hazards in the water (Gopalan, 1999). Plant roots are generally useful tools in biological tests, because they are the first structures to be exposed to chemical variations in the water and soil (Fiskesjö, 1988).

Among the plants commonly used as indicators for studies of potential toxicity of River water, Allium cepa L. constitutes a convenient system for the analysis of anatomical (root growth, deformity, twist) and microscopic parameters (chromosome abnormalities, altered mitotic index (MI), and micronucleus (MN) formation) (Egito et al., 2007). Induction of micronucleus formation, the outcome of chromosome breaks/fragments or spindle poisoning which induces an anomalous disjunction of chromosome at anaphase, has usually been considered a genotoxic indicator (Dash et al., 1988; Grover and Kaur, 1999; Chandra et al., 2005). Onion is available year round and its roots show fast growth (Nielsen and Rank, 1994; Ateeq et al., 2002). The Allium cepa test has been demonstrated useful for biological monitoring of waters contaminated with heavy metals and cyanides (Staykova et al., 2005). The Allium/Vicia root tip chromosome aberration assay has also been adopted by the International Program on Plant Biossays (IPPB) for monitoring or testing environmental pollutants (Ma, 1999).

This study describes the growth of Allium cepa roots treated with water sampled at two sites of the Brazilian River Paraíba do Sul in the years of 2005 and 2006, for evaluation of the cytotoxic potential of this river water. $\mathrm{MI}$ and $\mathrm{MN}$ frequency were also studied in roots of
Allium cepa treated with water sampled in the year of 2005 for investigation of potential cytotoxic and genotoxic effects promoted by the river water.

\section{Materials and Methods}

\subsection{Sampling}

Water samples from the River Paraíba do Sul, at the cities of Tremembé (22 $57^{\circ} 40^{\prime \prime} \mathrm{S}$ and $\left.45^{\circ} 33^{\prime} 10^{\prime \prime} \mathrm{W}\right)$ and Aparecida (22 $50^{\prime} 40^{\prime \prime} \mathrm{S}$ and $\left.45^{\circ} 14^{\prime} 04^{\prime \prime} \mathrm{W}\right)$ (Figure 1) were collected in 2005 and 2006. August was selected as the period for collection, since it is a dry month in the region (Fisch, 1999). The monthly values of precipitation at the Meteorological Station UNITAU/INMET at Taubaté were $1.7 \mathrm{~mm}$ (August 2005) and $2.9 \mathrm{~mm}$ (August 2006). A $20 \mathrm{~L}$ bucket was used for collecting the samples. The water was collected at bridges over the River passing alongside the mentioned cities. A mixture was composed from water sampled from the margins and the middle of the River, and transferred to $40 \mathrm{~L}$ containers. Physicochemical and microbiological parameters for the water of the River Paraíba do Sul at Tremembé and Aparecida and for the control water in August 2005 and 2006, were obtained from official reports (CETESB, 2005; 2006; SABESP, 2005; 2006).

The Allium cepa bulbs were obtained from a local trade source and originated from Petrolândia (in the Brazilian state of Santa Catarina). Forty onion bulbs of appropriate size $(3-3.5 \mathrm{~cm})$ had their ring of the root primordia primarily suspended in jars filled with clean tap water, for 48 hours, in order to demonstrate their viability for root growth, when the newly emerged roots were of 1.5-2.0 cm. The jars were kept protected from direct sunlight. Then, eight bulbs were chosen at random, per year, for treatment with the River water at the two mentioned cities plus the negative and positive controls (two bulbs each), which lasted from 24 to 120 hours.

Negative (no effect on the cell samples) and positive (effect on the cell samples, promoting mitotic index inhibition and elevated frequency of micronucleus) controls were used. The negative control consisted of tap water and the positive control for the year of 2005 consisted of $8 \mathrm{mM}$ ethylene diaminotetra acetic acid (EDTA, CAS\# 60004) (Grant, 1982) and for the year of 2006 consisted of $4 \mathrm{mg.L}$ methyl methanesulfonate (MMS, CAS\# 66273) (Rank and Nielsen, 1993; 1994; 1997; 1998; Grant, 1998; Grant and Owens, 2006). The choice of different drugs as positive controls depended on operational facilities, considering that both of them are effective as promoters of mitotic index inhibition and of increasing levels of micronucleus production (Grant, 1982; Rank and Nielsen, 1993; 1994; 1997; 1998; Grant, 1998; Grant and Owens, 2006). Daily measurements of the length of all of the roots grown from each bulb were carried out throughout the assay.

For determination of the microscopic parameters, another forty bulbs were used. They were subjected for 24 hours to treatments ( 10 bulbs each) as follows: tap water (negative control); $8 \mathrm{mM}$ ethylene diaminetetra acetic acid 


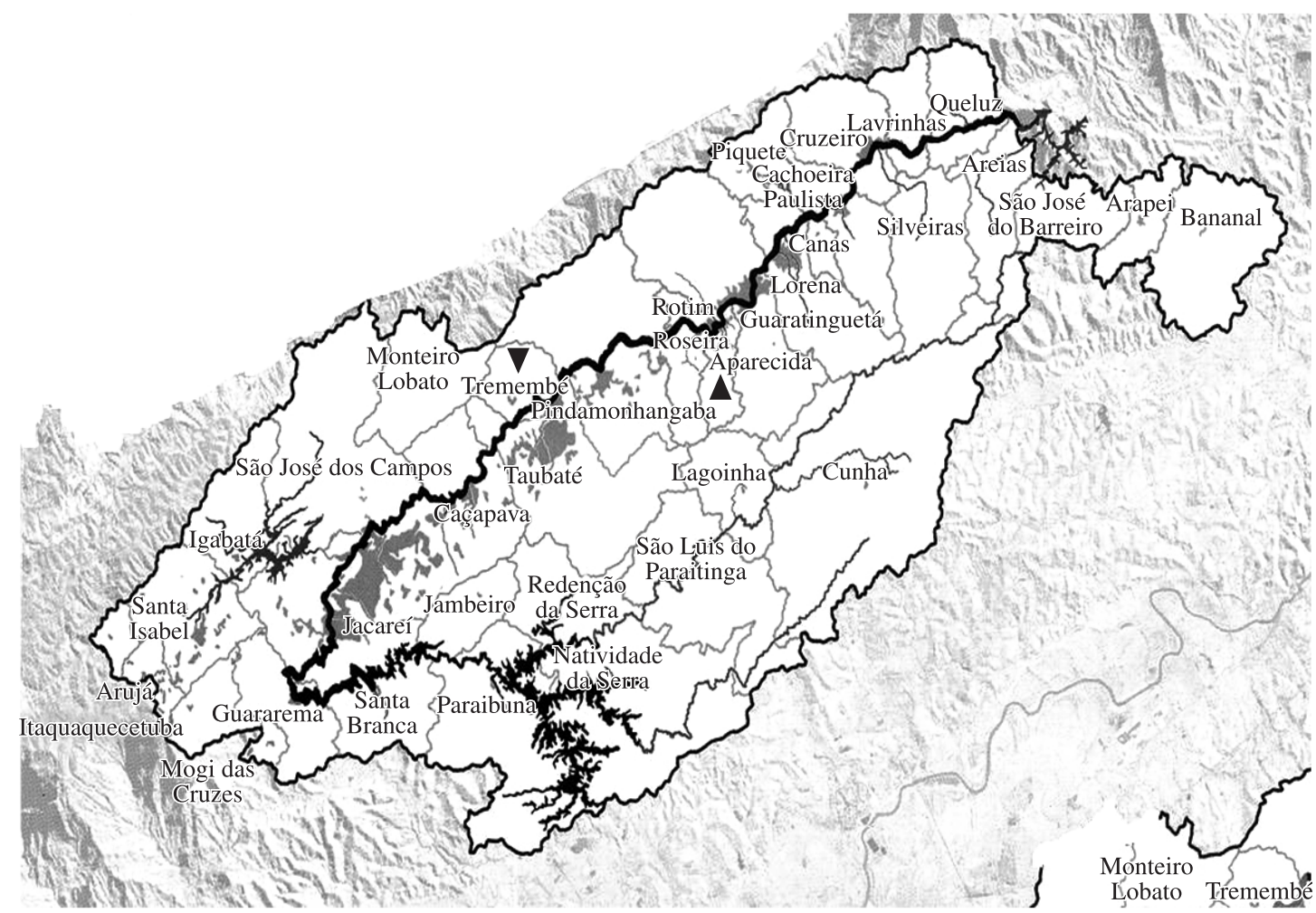

Figure 1. Indication of the cities (Tremembé and Aparecida) (red triangles) at which the water was sampled from the River Paraíba do Sul.

- EDTA (positive control); and water sampled from the sites of Tremembé and Aparecida.

\subsection{Allium test}

All root tips were fixed in absolute ethanol-glacial acetic acid 3:1 (volume/volume ) for 5 minutes and subjected to the Feulgen reaction en bloc. The acid hydrolysis pertinent to the Feulgen reaction was carried out in $4 \mathrm{M} \mathrm{HCl}$ at $24{ }^{\circ} \mathrm{C}$ for 75 minutes. Each stained root was squashed between slide and coverslip, and the squashes frozen in liquid nitrogen for the coverslip removal, and air dried. The preparations were then counterstained with Fast Green at pH 2.7 (Mello and Vidal, 1980), rinsed in distilled water, air dried, cleared in xylene, and mounted in Canada balsam. The observations were done under a Zeiss binocular light microscope (Oberkochen, Germany), using a CP achromat 40/0.65 objective.

$\mathrm{MI}$ and the MN frequency were determined by examination of 2,000 cells per slide, using 3-5 root tips from each bulb. The number of bulbs used depended on the availability of roots produced. The slides were examined from right to left, up end down, and the first 2,000 cells were scored for $\mathrm{MI}$ and $\mathrm{MN}$ frequency.

\subsection{Statistical analysis}

Data on root length, MI, and the MN frequency were compared using ANOVA and the Tukey test. Variance heterogeneity was tested. Data on root length regarding the Tremembé site and the negative control in the year of 2005 were compared by a Welch test ( $t$-test for different variances). The analyses were done using Statistica (Tulsa, USA, 2005) and Statsdirect (London, England, 2006) software.

\section{Results}

As regards the temporal analysis of data obtained for the growing Allium cepa root length (Figure 2), no general difference was statistically found with the different treatments and years. There was a decrease in growth in roots treated with the water collected at Tremembé (in 2005) in comparison with the control (Figure 2) $(\mathrm{p}<0.05)$. As regards the water collected at Aparecida (in 2005), there was a certain delay in growth of roots treated with this water in comparison with the control (Figure 2).

Based on a non-temporal analysis of the growth of the Allium cepa roots in the years of 2005 and 2006, no significant difference was detected when comparing results for the water collected from the two River sites and the negative control. However, the results obtained for Aparecida apparently indicated that the roots grew less when treated with the water sampled in the year of 2005 compared with the results obtained with the water sampled at the same site in 2006 (Figure 3).

A significant decrease in the MI values was demonstrated in cells of the Allium cepa roots treated with the water collected from the River Paraíba do Sul at the cities of Tremembé and Aparecida in the year of 2005 (Table 1). No significant difference was found in the MN 


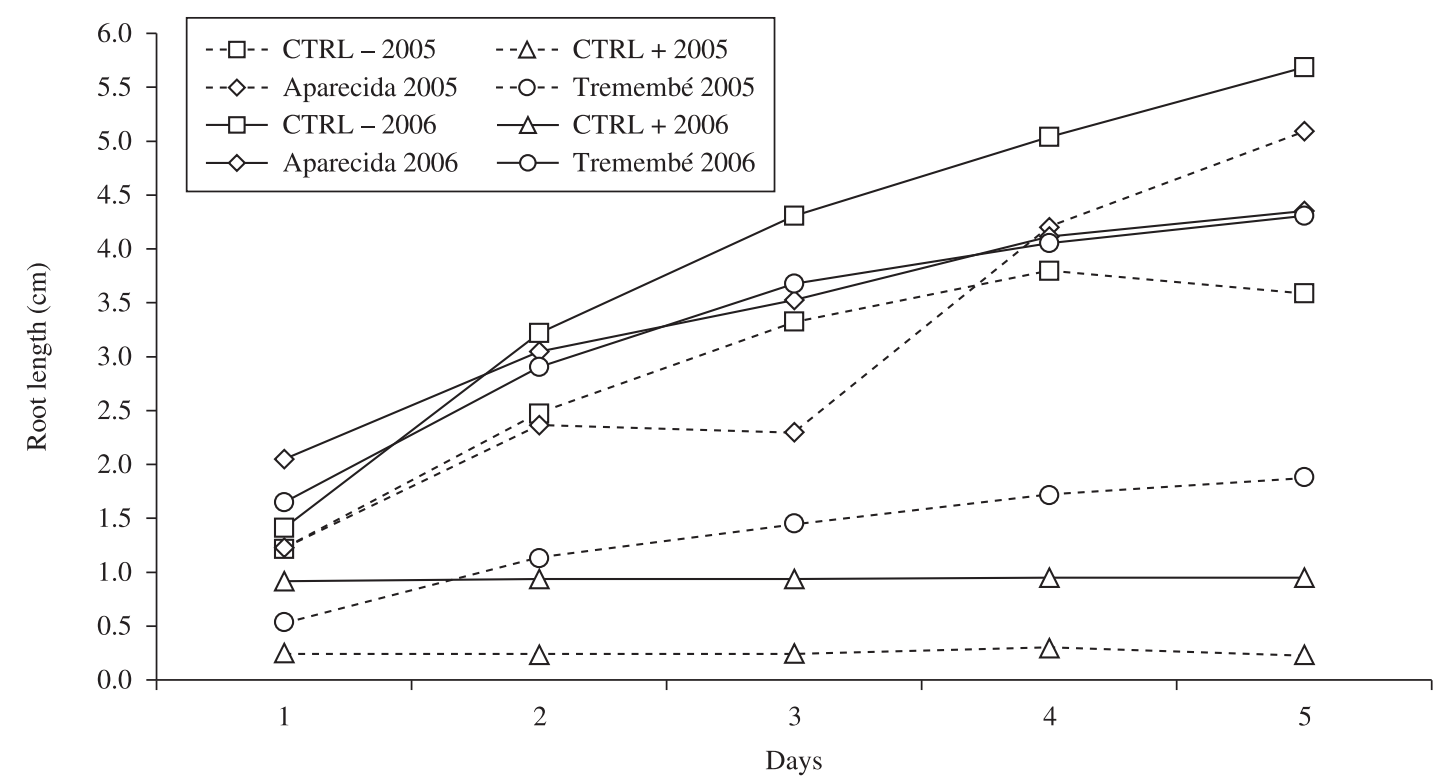

Figure 2. Growth of Allium cepa roots along the period of 5 days (120 hours) of treatment with the sampled water of the River Paraiba do Sul [years of 2005 (straight lines) and 2006 (dashed lines)]. Each point represents the arithmetic mean of six measurements. CTRL) controls; $\triangle$ ) positive; and $\square$ ) negative.

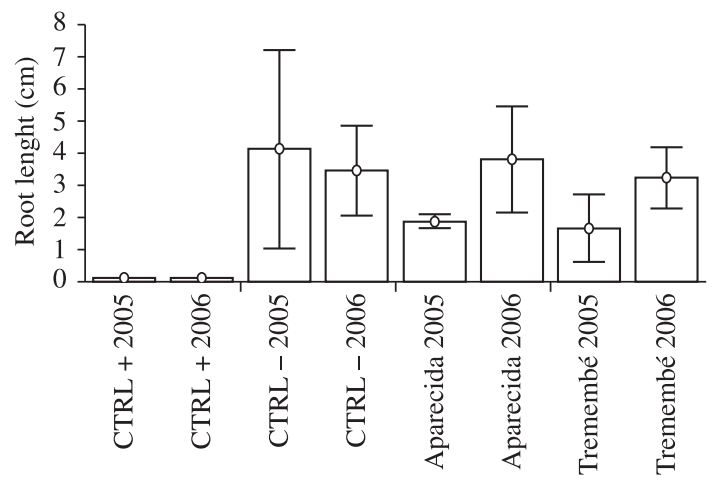

Figure 3. Cumulative growth (mean \pm SE) along the 120 hours treatment of Allium cepa roots with the water of the River Paraíba do Sul sampled at the cities of Tremembé and Aparecida, discriminating results obtained in the year of 2005 separated from those in the year of 2006. CTRL) controls.

frequency with the same treatments regarding the same year (Table 1).

\section{Discussion}

Many types of assays for evaluation of cytotoxicity and genotoxicity employing microorganisms and mammalian cells have been used for monitoring complex environmental samples such as River water. Plant assays and the Allium cepa test, particularly, have some advantages over microbial and mammalian cell tests because they are highly sensitive to many environmental pollutants (Fiskesjö, 1985), including heavy metals (Panda et al., 1996; Palacio et al., 2005), and are also useful for monitoring the potential synergistic
Table 1. Changes in MI and MN for Allium cepa roots treated with water from the River Paraíba do Sul sampled at Tremembé and Aparecida in the year of 2005.

\begin{tabular}{lccc}
\hline \multicolumn{1}{c}{ Water } & $\begin{array}{c}\text { MI } \\
\mathbf{X} \pm \mathbf{S E}\end{array}$ & $\begin{array}{c}\mathbf{M N} \\
\mathbf{X} \pm \mathbf{S E}\end{array}$ & $\begin{array}{c}\text { Total cells } \\
\text { scored }\end{array}$ \\
\hline CTRL - & $9.71 \pm 1.99$ & $0.21 \pm 0.15$ & 78,000 \\
CTRL + & $0.44 \pm 0.07 *$ & $* *$ & 68,000 \\
River site at & $5.27 \pm 0.77 *$ & $0.15 \pm 0.09$ & 64,000 \\
Tremembé & & & \\
River site at & $4.96 \pm 0.57 *$ & $0.09 \pm 0.04$ & 70,000 \\
Aparecida & & & \\
\hline
\end{tabular}

* Statistically different from the control at the $\mathrm{p}<0.05$ level by Tukey test.; CTRL -) negative control; CTRL +) positive control; and **Samples too small to be tested.

effects of mixtures of pollutants, including hydrophylic and lipophylic chemicals. Furthermore, test plants can be directly exposed to complex mixtures or environmental samples either in the laboratory or in situ. Because of the large size of their chromosomes, some higher plants are suitable for cytological analysis and the responses so obtained are highly correlated with those seen in other biological systems, thus making plant tests also good candidates for evaluating the genotoxicity of environmental samples (Fiskesjö, 1985; 1988; Palacio et al., 2005; Egito et al., 2007).

In the present study, the potential toxicity of the water of the River Paraíba do Sul was evaluated with the Allium cepa test by analysing one macroscopic parameter, the root length, and microscopic parameters such as the MI and the $\mathrm{MN}$ frequencies in the plant roots treated with the tested water. Plant root growth inhibition has been considered a toxicity indicator since it may result from a certain inhibi- 
tion of cell division (Fiskesjö, 1985; Odeigah et al., 1997; Babatunde and Bakare, 2006; Egito et al., 2007). Changes in MI estimate the altered frequency of cell division and are an indication that cell proliferation is affected (Marcano et al., 2004). Induction of micronucleus formation is generally considered an indication of genotoxicity (Dash et al., 1988; Grover and Kaur, 1999; Chandra et al., 2005).

Our results did not show differences in terms of root growth inhibition in Allium cepa treated with the water sampled from the River in the years of 2005 and 2006, except for the roots exposed to the water sampled at Tremembé in 2005. In this case, it is suggested that, in that particular year and place, the River water was potentially cytotoxic, in a similar way as that reported by other authors using the same assay for other Rivers (Palácio et al., 2005; Babatunde and Bakare, 2006; Egito et al., 2007).

As regards the growth delay at day 3 in roots treated with the water sampled at Aparecida in 2005, if considered as an isolated event, it might be interpreted as an episodic finding, since no difference was detected from there on. However, in terms of an atemporal analysis of the root growth, a slower growth was found for the roots treated with the water sampled in 2005 compared to the year of 2006, at Aparecida. In addition, considering the decrease in MI in the Allium cepa roots treated with the River water sampled at the two mentioned sites in 2005, a cytotoxic effect by substances interfering with the cell cycle may be considered. This hypothesis is in agreement with published data which have revealed a deep mitodepressive effect promoted in Allium cepa by cytotoxic substances like heavy metals, polycyclic hydrocarbons, herbicides, industrial and domestic discharges and other drugs (Fiskesjö, 1981a,b; Liu et al., 1992; Odeigah et al., 1997; Bakare and Wale-Adeyemo, 2004; Marcano et al., 2004; Grisolia et al., 2005; Fernandes et al., 2007).

Indeed, physicochemical and microbiological analyses of the water of the River Paraíba do Sul indicated parameters with levels not above those tolerated by the CONAMA Statutory Instrument 357/2005, with the exception of dissolved aluminium, total iron, and thermotolerant E. coli (CETESB, 2005, 2006). A report from CETESB for August 2006 has revealed 0.12 and $0.15 \mathrm{mg} . \mathrm{L}$ dissolved aluminium in water collected at Tremembé and Aparecida, respectively (maximum tolerated, $0.1 \mathrm{mg}$.L). Total iron represented values above the maximum tolerated of $0.3 \mathrm{mg} . \mathrm{L}$ ( 0.49 and $0.97 \mathrm{mg} . \mathrm{L}$ in the water collected at Tremembé and Aparecida, respectively) only in the year of 2005 (CETESB, 2005, 2006). Thermotolerant E. coli values were 2,300 and 3,300 UFC/100 mL (maximum tolerated, 1,000 UFC/100 mL) in August 2005 and 2006, respectively, in the water sampled at Tremembé, and 24,000 and 33,000 UFC/100 mL in August 2005 and 2006, respectively, in the water sampled at Aparecida (CETESB, 2005; 2006). The tap water used as negative control in this study was free from E. coli (SABESP, 2005, 2006). In summary, parameter levels much higher than those officially tolerated are apparently those concerned with $E$. coli, especially in the water sampled in the years of 2005 and 2006 at the city of Aparecida, and possibly provided by fecal contamination.

Therefore, if a cytotoxic potential for the water sampled from the River Paraíba do Sul at Tremembé and Aparecida was promoted by the E. coli levels in 2005, up to the point of affecting the MI values in Allium cepa, we could anticipate that the same will occur for the samples obtained in 2006, the analysis of which is in progress. If the cytotoxic potential is promoted only by the total iron level, such an effect is expected not to occur for the water obtained at both cities in 2006. No data on free aluminium have been found in the report by CETESB for 2005.

Although a cytotoxic effect could be assumed for the tested water, no genotoxic effect was demonstrated for the River water sampled in 2005 at Tremembé and Aparecida, since no change in $\mathrm{MN}$ formation in Allium cepa cells was elicited by it. Indeed, tests on frequency of chromosome abnormalities could furnish additional confidence to MN data in terms of genotoxic effects. Work in progress is being undertaken for the analysis of chromosomes of the Allium cepa roots treated with the water of the River Paraíba do Sul.

The results obtained with EDTA and MMS are in agreement with the expected effect of these drugs as good positive controls (Grant, 1982; 1998; Rank and Nielsen, 1993; 1994; 1997; 1998; Grant and Owens, 2006).

Present findings reinforce the sensitivity of the Allium cepa test, especially concerning the MI evaluation, for monitoring river waters, thus serving as a tool for the early warning of the presence of cytotoxins in the hydric environment. We consider that this test could even be recommended for the prescreening of cytotoxicity in wastewaters.

In conclusion, considering the data involving root length growth and especially MI values, a cytotoxic potential is suggested for the water of the River Paraíba do Sul at Tremembé and Aparecida, in 2005. On the other hand, since in this year the MN frequency was not affected by the river water treatments, genotoxicity is not assumed for the river water sampled at the mentioned places. The estimation of MI values for material obtained in the year of 2006 is still required in order to establish a better relationship with the root growth and physicochemical and microbiological parameters reported by CETESB (2006), as mentioned above.

Acknowledgements - The authors are indebted to Mr. José Roberto Schmidt (Director of CETESB, Jacareí, Brazil) and Dr. Adekunle A. Bakare (Cell Biology and Genetics Unit, University of Ibadan, Nigeria) for providing useful information in assisting with the literature on the environmental sciences. This research received financial support from the University of Taubaté/SP - Brazil.

\section{References}

ATEEQ, B., FARRA, MA., ALI, MN. and AHMAD, W., 2002. Clastogenicity of pentachlorophenol, 2,4-D and butachlor evaluated by Allium root tip test. Mutation Research, vol. 514, no. 1-2, p. 105-113.

BABATUNDE, BB. and BAKARE, AA., 2006. Genotoxicity screening of wastewaters from Agbara industrial estate, Nigeria evaluated with the Allium test. Pollution Research, vol. 25, no. 2, p. 227-234.

BAKARE, AA. and WALE-ADEYEMO, AR., 2004. The mutagenic and cytotoxic effects of leachates from domestic solid wastes and Aba- 
Eku landfill, Nigeria on Allium cepa. Nature Environment and Pollution Technology, vol. 3, no. 4, p. 455-462.

CABRERA, GL. and RODRIGUEZ, DMG., 1999a. Genotoxicity of leachates from a landfill using three bioassays. Mutation Research, vol. 426, no. 2, p. 207-210

1999b. Genotoxicity of soil from farmland irrigated with wastewater using three plant bioassays. Mutation Research, vol. 426, no. 2, p. 211-214.

CABRERA, GL., RODRIGUEZ, DMG. and MARURI, AB., 1999. Genotoxicity of the extracts from the compost of the organic and the total municipal garbage using three plant bioassays. Mutation Research, vol. 426, no. 2, p. 201-206

Companhia de Tecnologia e Saneamento Ambiental - CETESB. 2002. Relatório de qualidade das águas interiores do Estado de São Paulo. São Paulo: CETESB. 263p.

2005. Resultados dos parâmetros e indicadores de qualidade das águas interiores do Estado de São Paulo. São Paulo: CETESB. Available from: http://www.cetesb.sp.gov.br/Agua/rios/relatorios.asp. Access in: 10/01/2007

2006. Resultados dos parâmetros e indicadores de qualidade das águas interiores do Estado de São Paulo. São Paulo: CETESB. Available from: http://www.cetesb.sp.gov.br/Agua/rios/relatorios.asp. Access in: $10 / 01 / 2007$

CHANDRA, S., CHAUHAN, LKS., MURTHY, RC., SAXENA, PN., PANDE, PN. and GUPTA, SK., 2005. Comparative biomonitoring of leachates from hazardous solid waste of two industries using Allium test. The Science of the Total Environment, vol. 347, no. 1-3, p. 46-52.

Conselho Nacional do Meio Ambiente - CONAMA, 2005. Resolução 357. Brasília: CONAMA. 23p.

DASH, S., PANDA, KK. and PANDA, BB., 1988. Biomonitoring of low levels of mercurial derivatives in water and soil by Allium micronucleus assay. Mutation Research, vol. 203, no. 1, p. 11-21.

EGITO, LCM., MEDEIROS, MG., MEDEIROS, SRB. and AGNEZLIMA, LF., 2007. Cytotoxic and genotoxic potential of surface water from the Pitimbu river, northeastern/RN Brazil. Genetics and Molecular Biology, vol. 30, no. 2, p. 435-441.

EVSEEVA, TI., GERAS'KIN, SA. and SHUKTOMOVA, II., 2003. Genotoxicity and toxicity assay of water sampled from a radium production industry storage cell territory by means of Allium-test. Journal of Environmental Radioactivity, vol. 68, no. 3, p. 235-248.

FERNANDES, TCC., MAZZEO, DEC. and MARIN-MORALES, MA., 2002. Mechanism of micronuclei formation in polyploidizated cells of Allium cepa exposed to trifluralin herbicide. Pesticide Biochemistry and Physiology, vol. 88, no. 3, p. 252-259.

FISCH, G., 1999. Distribuição da precipitação em Taubaté, Vale do Paraíba (SP). Revista Biociências, vol. 5, no. 2, p. 7-11.

FISKESJÖ, G., 1981a. Benzo[a]pyrene and N-methyl-N'-nitro-Nnitrosoguanidine in the Allium test. Hereditas, vol. 95, no. 1, p. 155-162.

1981b. Chlorinated phenoxyacetic acids and chlorophenols in the modified Allium test. Chemico Biological Interactions, vol. 34, no. 3 , p. 333-334.

1985. The Allium test as a standard in environmental monitoring. Hereditas, vol. 102, no. 1, p. 99-112.

1988. The Allium test - an alternative in environmental studies: the relative toxicity of metal ions. Mutation Research, vol. 197, no. 2, p. $243-260$.

GOPALAN, HN., 1999. Ecosystem health and human well being: the mission of the international programme on plant bioassays. Mutation Research, vol. 426, no. 2, p. 99-102.

GRANT, WF., 1982. Chromosome aberration assays in Allium: a report of the U. S. Environmental Protection Agency Gene-Tox Program. Mutation Research, vol. 99, no. 3, p. 273-291

1998. Chromosome aberration assays in Crepis for the study of environmental mutagens. Mutation Research, vol. 410, no. 3, p. 291-307.

1999. Higher plant assay for the detection of chromosomal aberrations and gene mutations - a brief historical background on their use for screening and monitoring environmental chemicals. Mutation Research, vol. 426, no. 2, p. 107-112.
GRANT, WF. and OWENS, ET., 2006. Zea mays assays of chemical/ radiation genotoxicity for the study of environmental mutagens. Mutation Research, vol. 613, no. 1, p. 17-64.

GRISOLIA, CK., OLIVEIRA, ABB. and BONFIM, H., 2005. Genotoxicity evaluation of domestic sewage in a municipal wastewater treatment plant. Genetics and Molecular Biology, vol. 28, no. 2, p. 334-338.

GROVER, IS. and KAUR, S., 1999. Genotoxicity of wastewater sample from sewage and industrial effluent detected by the Allium root anaphase aberration and micronucleus assays. Mutation Research, vol. 426, no. 2 , p. $183-188$.

LIU, D., JIANG, W. and LI, M., 1992. Effects of trivalent and hexavalent chromium on root growth and cell division of Allium cepa. Hereditas, vol. 117 , no. 1 , p. $23-29$.

MA, TH., 1999. The international program on plant bioassays and the report of the follow-up study after the hands-on workshop in China. Mutation Research, vol. 426, no. 2, p. 103-106.

MAJER, BJ., GRUMMT, T., UHL, M. and KNASMÜLLER, S., 2005. Use of plant bioassays for the detection of genotoxins in the aquatic environment. Acta Hydrochimica et Hydrobiologica., vol. 33, no. 1, p. $45-55$.

MARCANO, L., CARRUYO, I., CAMPO, AD. and MONTIEL, X., 2004. Cytotoxicity and mode of action of maleic hydrazide in root tips of Allium cepa L. Environmental Research, vol. 94, no. 2, p. 221-226.

MATSUMOTO, ST., MANTOVANI, MS., MALAGUTI, MIA., DIAS, AL., FONSECA, IC. and MARIN-MORALES, MA., 2006. Genotoxicity and mutagenicity of water contaminated with tannery effluents and comet assay using the fish Oreochromis niloticus and chromosome alterations in onion root-tips. Genetics and Molecular Biology, vol. 29, no. 1, p. 148-158.

MELLO, MLS. and VIDAL, BC., 1980. Práticas de biologia celular. 1 ed. São Paulo: Edgard Blücher; Funcamp. p. 57-58.

NIELSEN, MH. and RANK, J., 1994. Screening of toxicity and genotoxicity in wastewater by the use of the Allium test. Hereditas, vol. 121 , no. 3 , p. $249-254$

ODEIGAH, O., NURUDEEN, O. and AMUND, OO., 1997. Genotoxicity of oil field wastewater in Nigeria. Hereditas, vol. 126, no. 2, p. 161-167.

PALACIO, SM., ESPINOZA-QUIÑONES, FR., GALANTE, RM., ZENATTI, DC., SEOLATTO, AA., LORENZ, EK., ZACARKIM, CE., ROSSI, N., RIZZUTTO, MA., TABACNIKS, MH., 2005. Correlation between heavy metal íons (Copper, Zinc, Lead) concentrations and root length of Allium cepa L. in polluted river water. Brazilian Archives of Biology and Technology, vol. 48, no. spec., p. 191-196.

PANDA, KK., PATRA, J. and PANDA, BB., 1996. Induction of sister chromatid exchanges by heavy metal salts in root meristem cells of Allium cepa L. Biologia Plantarum, vol. 38, no. 4, p. 555-561.

RANK, J. and NIELSEN, MH., 1993. A modified Allium test as a tool in the screening of the genotoxicity of complex mixtures. Hereditas, vol. 118 , no. 1 , p. $49-53$.

1994. Screening of toxicity and genotoxicity in wastewater by the use of the Allium test. Hereditas, vol. 121, no. 3, p. 249-254

1997. Allium cepa anaphase-telophase root tip chromosome aberration assay on N-methyl-N-nitrosourea, maleic hydrazide, sodium azide, and ethyl methanesulfonate. Mutation Research, vol. 390, no. 1-2, p. 121-127.

1998. Genotoxicity testing of wastewater sludge using the Allium cepa anaphase-telophase chromosome aberration assay. Mutation Research, vol. 418, no. 2-3, p. 113-119.

Companhia de Saneamento Básico do estado de São Paulo- SABESP., 2005. Informações da qualidade das águas do estado de São Paulo. Available from: http://www.sabesp.com.br/sabesp/filesmng.nsf/D4E25A3C5E1ACBE6832 57209006DDE3B/\$File/relatorio_qualidade.pdf. Access in: 17/01/2007

2006. Informações da qualidade das águas do estado de São Paulo; Available from: http://www.sabesp.com.br/sabesp/filesmng.nsf/5 2BB882D899FBD3883257251004ABB84/\$File/rel_ago06.pdf. Access in: $17 / 01 / 2007$

STAYKOVA, TA., IVANOVA, EN. and VELCHEVA, IG., 2005. Cytogenetic effect of heavy-metal and cyanide in contaminated waters from the region of southwest Bulgaria. Journal of Cell and Molecular Biology, vol. 4, no. 1, p. 41-46. 